\title{
APEM
}

\section{An implementation of lean scheduling in a job shop environment}

\author{
Haider, A. ${ }^{a,}{ }^{,}$, Mirza, J. ${ }^{a}$ \\ aniversity of Engineering and Technology, Department of Industrial Engineering, Taxila, Pakistan
}

\begin{abstract}
A B S T R A C T
Globalization has demanded innovative manufacturing and continuous improvement in order to stay competitive. This need has compelled the manufacturing world to devise strategies for producing cost-efficient parts without compromising quality. The Toyota Production System was at the beginning of such initiatives. It was successful in addressing cost through elimination of non-value-added time and quality by monitoring and controlling the productions of defective parts. Lean thinking originated from the Toyota Production System and inherited its concepts and methodology. In contrast to the Toyota Production System, the implementation of lean has been proposed in almost every domain of life. In the manufacturing domain it is a common misconception that lean is suitable for mass production only. This research has been built upon the belief that lean is for everything and has challenged this stereotype by implementing it within a job shop environment. A manufacturing industry was selected that was rebuilding battlefield tanks. The existing system was suffering delays and missing delivery targets due to uncertain and costly production. The proposed and existing systems were modeled and simulated using Arena 10.0 software. This work was successful in reducing the manufacturing-led time, work in process inventory and average cycle times with a reduction in cost and space utilization. Cost benefit analysis was performed showing that the proposed system would be beneficial after 1500 parts. We are further expanding our proposed approach towards the tool manufacturing shop in order to study the impact of lean and its suitability for scheduling in job shops.
\end{abstract}

\section{ARTICLE INFO}

Keywords:

Manufacturing

Toyota Production System

Lean thinking

Job shop production

One piece flow

Manufacturing simulation

*Corresponding author:

aftab775@yahoo.com

(Haider, A.)

Article history:

Received 30 October 2014

Revised 4 February 2015

Accepted 8 February 2015 


\title{
Izvedba vitkega terminiranja v okolju naročniške proizvodnje
}

\author{
Haider, A. ${ }^{a,}{ }^{*}$, Mirza, J. ${ }^{a}$ \\ ${ }^{a}$ University of Engineering and Technology, Department of Industrial Engineering, Taxila, Pakistan
}

\section{POVZETEK}

Globalizacija zahteva inovativno proizvodnjo in neprestano izboljševanje podjetij, da bi ostala konkurenčna. To od podjetij zahteva izvajanje strategij za stroškovno učinkovito proizvodnjo izdelkov, brez ogrožanja njihove kakovosti. Toyotin proizvodni sistem je ena izmed takšnih iniciativ, ki znižuje stroške z odpravo aktivnosti, ki ne dodajajo vrednosti ter zagotavlja kakovost s pomočjo spremljanja in kontrole proizvodnje neustreznih izdelkov. Koncept vitkega razmišljanja izhaja iz Toyotinega proizvodnega sistema in je nasledil njegove koncepte in metodologije. Koncept vitkosti lahko najdemo v vsakodnevnem življenju in ni omejen le na proizvodna okolja. V proizvodnih okoljih vlada napačno prepričanje, da je koncept vitkosti primeren zgolj za velikoserijsko proizvodnjo. Zato pričujoča raziskava dokazuje, da je koncept vitkosti primeren za vsa okolja. Osredotoča se na okolje naročniške proizvodnje. Izbrali smo industrijo, ki se ukvarja z rekonstrukcijo vojaških tankov. Obstoječi sistem je povzročal zamude in kršitve dobavnih rokov zaradi negotovosti in drage proizvodnje. Nov predlagan sistem smo modelirali s pomočjo programske opreme Arena 10.0. Dosegli smo skrajšanje proizvodnih pretočnih časov in znižanje procesnih zalog $s$ sočasnim znižanjem stroškov in učinkovitejšo izrabo prostora. Izvedli smo analizo stroškov in koristi, ki je pokazala, da predlagan sistem postane koristen pri proizvodnji nad 1500 izdelkov. Naš pristop smo še dodatno preizkusili v proizvodnji orodij, da bi lahko preučili vpliv vitkosti in njene primernosti na področju terminiranja.
\end{abstract}

\section{PODATKI O ČLANKU}

Ključne besede:

Proizvodnja

Toyotin proizvodni sistem

Vitko razmišljanje

Naročniška proizvodnja

Enoizdelčni tok

Simulacija proizvodnje

*Kontaktna oseba: aftab775@yahoo.com

(Haider, A.)

Zgodovina članka:

Prejet 30. oktobra 2014

Popravljen 4. februarja 2015

Sprejet 8. februarja 2015 


\section{References}

[1] Thornton, P. (2010). The global manufacturing sector: Current issues, Chartered Institute of Management Accountants, London, UK, from http://www.cimaglobal.com/Documents/Thought_leadership_docs/Global_manufacturing_report.pdf, accessed February 4, 2015.

[2] Ohno, T. (1988). Toyota production system: Beyond large-scale production, Productivity Press, Portland, USA.

[3] Kovacheva, A.V. (2010). Challenges in lean implementation: Successful transformation towards lean enterprise, Master thesis, Aarhus School of Business, University of Aarhus, Denmark, from http://pure.au.dk/portal-asbstudent/files/9093/ak83188.pdf, accessed February 4, 2015.

[4] Fujimoto, T. (2012). The evolution of production systems: Exploring the sources of Toyota's competitiveness, Annals of Business Administrative Science, Vol. 11, 25-44, doi: 10.7880/abas.11.25.

[5] Kachru, U. (2009). Production \& Operations Management, Excel Books, India, New Delhi.

[6] Georgescu, D.D. (2011). Lean thinking and transferring lean management - The best defence against an economic recession?, European Journal of Interdisciplinary Studies, Vol. 3, No. 1, 4-20.

[7] Haider, A.A, Jahanzaib, M., Akhtar, K. (2007). Experimental comparison of one piece flow production: A simulation based approach, European Journal of Scientific Research, Vol. 19, No. 1, 97-104.

[8] Imai, M. (1986). Kaizen: The key to Japan's competitive success, Random House Business Division, New York, USA.

[9] Maroofi, F., Dehghan, S. (2012). Performing lean manufacturing system in small and medium enterprises, International Journal of Academic Research in Accounting, Finance and Management Sciences, Vol. 2, No. 3, 156-163.

[10] Eng, C.K., Ching, H.W. (2014). Tool for mapping manufacturing critical-path time in job shop environment, Science International, Vol. 26, No. 4, 1585-1589.

[11] Assaf, R. (2014). Job shop lean production implementation using program evaluation and review technique (Pert), In: Proceedings of the 2014 International Conference on Industrial Engineering and Operations Management, Bali, Indonesia, 1554-1560.

[12] Modrák, V., Semančo, P. (2014). Cell design for transforming the job shop production process to lean, In: Handbook of Research on Design and Management of Lean Production Systems, IGI Global, 130-147, doi: 10.4018/9781-4666-5039-8.ch007.

[13] Irani, S.A. (2011). Job shop lean - Continuous improvement: No one solution for all, The Fabricator, Vol. 40, No. 2, 44-45.

[14] Djassemi, M. (2014). Lean adoption in small manufacturing shops: Attributes and challenges, The Journal of Technology, Management, and Applied Engineering, Vol. 30, No. 1, 2-10.

[15] Groover, M.P. (2007). Automation, production systems, and computer integrated manufacturing, 3rd edition, Prentice Hall, New Jersey, USA.

[16] Haider, A.A. Lean scheduling in high variety low volume environment, Master thesis, University of Engineering and Technology, Taxila, Pakitan.

[17] Bozzone, V. (2001). Speed to market: Lean manufacturing for job shops, $2^{\text {nd }}$ edition, AMACOM, New York, USA.

[18] Kelton, W.D., Sadowski, D.A., Sadowski, R.P. (2001). Simulation with Arena, $2^{\text {nd }}$ edition, McGraw-Hill Science, New York, USA. 